\title{
Syntheses and Crystal Structures of Vanadium and Iron Chloride Complexes with Diglyme
}

\author{
Saša Petriček* and Alojz Demšar \\ Faculty of Chemistry and Chemical Technology, Department of Inorganic Chemistry, Večna pot 113, \\ P.O.B. 537, SLO - 1001 Ljubljana, Slovenia \\ Tel.: +38614798512 \\ * Corresponding author: E-mail: sasa.petricek@fkkt.uni-lj.si
}

Received: 13-11-2014

Dedicated to the memory of Prof. Dr. Jurij V. Brenčič.

\begin{abstract}
A mononuclear molecular complex $f a c$ - $\left[\mathrm{VCl}_{3}(\right.$ diglyme $\left.)\right](\mathbf{1})$ resulted from the reaction of $\mathrm{VCl}_{3}$ and diglyme (diglyme $=$ di(2-methoxyethyl)ether) in dichloromethane. The violet complex $\mathbf{1}$ is a sensitive substance which slowly oxidized to a new, blue mononuclear molecular complex, $f a c-\left[\mathrm{VOCl}_{2}\right.$ (diglyme) $(2)$ in the presence of air.

The synthesis of iron(II), iron(III) complex $\left.[\mathrm{FeCl}(\text { diglyme })(\mathrm{THF})]_{2}\left[\mathrm{FeCl}_{4}\right)\right]_{2}(\mathbf{3})$ was achieved by the reaction of yellowgreen, partly oxidized $\mathrm{FeCl}_{2} \cdot 4 \mathrm{H}_{2} \mathrm{O}$, diglyme and chlorotrimethylsilane in tetrahydrofuran. The compound consists of dinuclear cations with octahedral environment of iron(II) and tetrahedral anions of iron(III). A pure iron(II) chloridediglyme complex $\left[\mathrm{FeCl}_{2}(\text { diglyme })\right]_{2}$ (4) was gained by the reaction of freshly prepared iron(II) chloride hydrate, diglyme and chlorotrimethylsilane in dichloromethane. Diglyme is coordinated in a meridional mode to octahedral iron(II) in dinuclear cations of $\mathbf{3}$ and in dinuclear molecules $\mathbf{4}$.
\end{abstract}

Keywords: Iron, Vanadium, Chloride, Di(2-Methoxyethyl)ether, mer-isomer, fac-isomer

\section{Introduction}

Applying a polyether diglyme as a ligand in syntheses of alkaline earth complexes is a common approach to prevent oligomerization by bridging ligands. ${ }^{1-4}$ Saturating a coordination sphere of a metal by the tridentate chelate ligand diglyme hinders 'metal - metal' contacts. The formation of two five-membered puckered rings increases the stability of complexes. Minimized intermolecular solid-state interactions in monomeric complexes resulted in an enhanced volatility in comparison to oligomeric complexes, which makes mononuclear alkaline earth complexes superior metal organic chemical vapor deposition (MOCVD) precursors. A prevailingly chelate bonding of digyme to metal centers in complexes is confirmed by the structural data in the CSD (version 5.35 updated May 2014) listing only about a dozen compounds of alkali metals, aluminum and lead with bridging diglyme molecules among numerous diglyme complexes.

Diglyme is a flexible O-donor ligand able to coordinate to a whole range of metals; not only earth alkaline
MOCVD precursors, ${ }^{1-4}$ but also lanthanide(III) halide complexes have been extensively studied. ${ }^{5-10}$ On the other hand, only a few examples of the first row $d$-block metal halide complexes with diglyme were prepared. They are either mononuclear molecular $\left[\mathrm{MCl}_{3}\right.$ (diglyme $\left.)\right](\mathrm{M}(\mathrm{III})=\mathrm{Sc}$, Ti),${ }^{11-12}\left[\mathrm{MX}_{2}(\right.$ diglyme $\left.)\right](\mathrm{X}=\mathrm{Cl}, \mathrm{M}(\mathrm{II})=\mathrm{Zn}, \mathrm{X}=\mathrm{I}, \mathrm{M}(\mathrm{II})$ $=\mathrm{Co}, \mathrm{Zn})$ complexes ${ }^{13-14}$ dinuclear $\left[\mathrm{MX}_{2}(\text { diglyme })\right]_{2}(\mathrm{X}=$ $\mathrm{Cl}, \mathrm{M}(\mathrm{II})=\mathrm{Mn}, \mathrm{Co}, \mathrm{Ni} ; \mathrm{X}=\mathrm{Br}, \mathrm{I}, \mathrm{M}(\mathrm{II})=\mathrm{Ni}$ ) or 1-D polymeric $\left[\mathrm{Co}_{2} \mathrm{Cl}_{4} \text { (diglyme) }\right]_{\mathrm{n}}{ }^{13-16} \mathrm{Metal} \mathrm{M}(\mathrm{II})$ ions in polymeric and dinuclear complexes are connected by halides to achieve a preferred octahedral environment. A great flexibility of diglyme is most clearly demonstrated in complexes with octahedral arrangement of donor atoms coordinated to $\mathrm{M}^{2+}$ or $\mathrm{M}^{3+}$ either in mer or fac geometry (Chart 1). All three oxygen atoms, O1, O2, O3, of diglyme and the central metal atom $\mathrm{M}$ are almost in the same plane with $\mathrm{O} 1-\mathrm{M}-\mathrm{O} 3$ angles in the range from 144 to $156^{\circ}$ in mer isomers. ${ }^{13-17}$ In fac isomers are the two planes, each through the central metal atom $\mathrm{M}$, the middle $(\mathrm{O} 2)$ and one of terminal oxygen atoms (O1 or $\mathrm{O} 3)$ in diglyme, nearly perpendicular to each other with $\mathrm{O} 1-\mathrm{M}-\mathrm{O} 3$ angles close to $90^{\circ} .{ }^{11-12}$ 

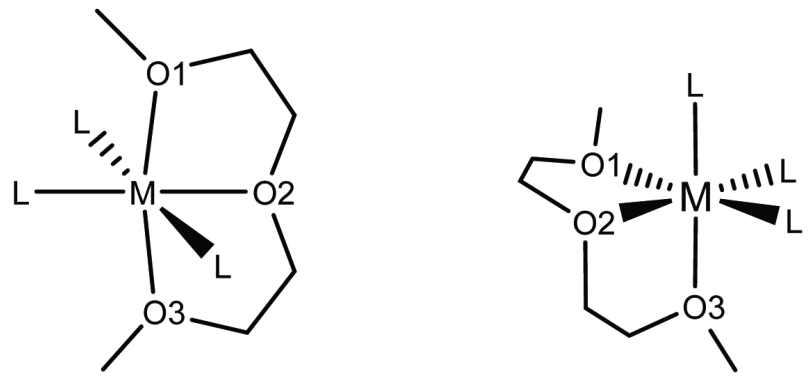

Chart 1. A mer- and a fac-isomer of $\left[\mathrm{M}(\right.$ diglyme $\left.) \mathrm{L}_{3}\right]$ complexes.

Dinuclear octahedral $\mathrm{M}(\mathrm{II})$ complexes $(\mathrm{M}=\mathrm{Mn}, \mathrm{Co}$, $\mathrm{Ni}$ and $\mathrm{Mg}$ ) with bridging halides and coordinated diglyme crystallize as mer isomers. ${ }^{13-17}$ Mononuclear scandium(III) and titanium(III) chloride complexes with diglyme crystallize as $f a c$ isomers, ${ }^{11-12}$ and a complex of a smaller ${ }^{18} \mathrm{Al}^{3+}$ is the $\operatorname{mer}$-[ $\mathrm{AlBr}_{3}$ (diglyme).$^{19}$

We prepared vanadium and iron chloride complexes with diglyme to continue our investigation of nuclearity and isomerism in the first row $d$-block metal halide complexes with this polyether. A correlation between structure and interesting magnetic properties of these compounds will be in focus of our research in the future.

\section{Experimental}

\section{1. General}

All the manipulations were carried out under an inert atmosphere. Vanadium(III) chloride (Aldrich, 97\%), iron(II) chloride tetrahydrate (Merck, 99\%), iron (Kemika, 95\%), hydrochloric acid (Riedel-de Haën, 32\%), diglyme (Fluka, 99.5\%) and chlorotrimethylsilane (Aldrich, 97.0\%) were used as delivered. Solvents were dried $\left(\mathrm{CH}_{2} \mathrm{Cl}_{2}\right.$ over calcium hydride, THF over $\mathrm{Na} / \mathrm{K}$ ) and distilled before use.

Suspensions of ground samples in Nujol were prepared in a dry box. IR spectra were recorded on a Perkin Elmer Spectrum 100 FT-IR spectrometer from 400 to $4000 \mathrm{~cm}^{-1}$.

Chlorine contents were determined by potentiometric titrations of chloride ions with silver nitrate. Elemental analyses were carried out on a Perkin-Elmer $2400 \mathrm{Se}-$ ries II CHN micro analyzer at the University of Ljubljana (Department of Organic Chemistry).

Powdered samples were sealed into tubes in a dry box and room temperature magnetic susceptibility measurements were performed by a Sherwood Scientific MBS-1 balance using $\mathrm{Hg}\left[\mathrm{Co}(\mathrm{NCS})_{4}\right]$ as a standard. Diamagnetic corrections were applied using Pascal's constants and the magnetic moments were calculated. ${ }^{20}$

\section{2. Synthesis of $\left[\mathrm{VCl}_{3}(\right.$ diglyme $\left.)\right], 1$}

\section{Method A)}

Solvent (THF, $30 \mathrm{~mL}$ ) and diglyme (1.484 g, 11.05 mmol) were added to $\mathrm{VCl}_{3}(0.810 \mathrm{~g}, 5.15 \mathrm{mmol})$ under an inert atmosphere. The suspension was stirred for three days at room temperature and then dried in vacuo. A considerable amount of unreacted $\mathrm{VCl}_{3}$ in the resulting powder product was detected by a CHN analysis and IR spectroscopy. In order to complete the reaction of $\mathrm{VCl}_{3}$ and diglyme additional solvent (THF, $30 \mathrm{~mL}$ ) and diglyme $(0.979 \mathrm{~g}, 7.29 \mathrm{mmol})$ were mixed with the powder product and stirred for 20 hours at $65^{\circ} \mathrm{C}$. This suspension was dried in vacuo. Although the powder product still contained unreacted $\mathrm{VCl}_{3}$ according to results of $\mathrm{CHN}$ analysis, a recrystallization of the product from dichloromethane resulted in crystals of $\mathbf{1}$.

\section{Method B)}

Solvent $\left(\mathrm{CH}_{2} \mathrm{Cl}_{2}, 30 \mathrm{~mL}\right)$ and diglyme $(0.601 \mathrm{~g}, 4.48$ $\mathrm{mmol}$ ) were added to $\mathrm{VCl}_{3}(0.433 \mathrm{~g}, 2.75 \mathrm{mmol})$ under an inert atmosphere. The suspension was stirred for a week at room temperature, then dried in vacuo, the complex $\mathbf{1}$ (0.798 g, 99.6\% yield) was gained. Anal. Calcd. mass fractions of elements, $w / \%$, for $\mathrm{C}_{6} \mathrm{H}_{14} \mathrm{Cl}_{3} \mathrm{O}_{3} \mathrm{~V}\left(M_{\mathrm{r}}=\right.$ 291.46) are: C, 24.72; H, 4.84; Cl, 36.49; found: C, 24.50; $\mathrm{H}, 4.78 ; \mathrm{Cl}, 36.51$. IR (1 in Nujol) $1302 \mathrm{~m}, 1275 \mathrm{w}, 1258$ w, 1240 m, 1199 m, 1098 s, 1070 s, 1040 s, 1014 s, 919 m, $879 \mathrm{w}, 856 \mathrm{~s}, 825 \mathrm{~m}, 588 \mathrm{w} \mathrm{cm}^{-1}$. Recrystallization from dichloromethane resulted in crystals of $\mathbf{1}$.

\section{3. Synthesis of $\left[\mathrm{VOCl}_{2}(\right.$ diglyme $\left.)\right], 2$}

Air leaking to a closed system during a crystallization of $\mathbf{1}$ by a slow evaporation of dichloromethane at a reduced pressure resulted in an oxidation of $\mathbf{1}$ to crystals of the blue complex 2. Anal. Calcd. mass fractions of elements, $w 1 \%$, for $\mathrm{C}_{6} \mathrm{H}_{14} \mathrm{Cl}_{2} \mathrm{O}_{4} \mathrm{~V}\left(M_{\mathrm{r}}=272.01\right)$ are: $\mathrm{C}$, 26.49; H, 5.19; found: C, 26.51; H, 5.22. IR (2 in Nujol) $1285 \mathrm{~m}, 1261 \mathrm{~s}, 1205 \mathrm{w}, 1193 \mathrm{w}, 1098 \mathrm{~s}, 1065 \mathrm{~s}, 1010 \mathrm{~s}$, $984 \mathrm{~s}, 924 \mathrm{~s}, 863 \mathrm{~s}, 796 \mathrm{~s}, 550 \mathrm{~m}, 438 \mathrm{~m} \mathrm{~cm}^{-1}$.

\section{4. Synthesis of $\left.[\mathrm{FeCl}(\operatorname{diglyme})(\mathrm{THF})]_{2}\left[\mathrm{FeCl}_{4}\right)\right]_{2}, 3$}

Solvent (THF, $30 \mathrm{~mL}$ ), diglyme (1.490 g, 11.1 $\mathrm{mmol})$ and $\left(\mathrm{CH}_{3}\right)_{3} \mathrm{SiCl}(15.103 \mathrm{~g}, 139 \mathrm{mmol})$ were added to a yellow-green partly oxidized $\mathrm{FeCl}_{2} \cdot 4 \mathrm{H}_{2} \mathrm{O}(1.092 \mathrm{~g}$, $5.49 \mathrm{mmol}$ ). The yellow suspension was stirred five days at room temperature. An attempt to evaporate solvent in vacuo resulted in a highly viscous brownish solution. After a week yellow crystals of the complex $\mathbf{3}$ grew out of the solution. IR (3 in Nujol) 1260 s, 1093 s, 1018 s, 866 w, $799 \mathrm{~s}, 465 \mathrm{w} \mathrm{cm}^{-1}$.

\section{5. Synthesis of $\left[\mathrm{FeCl}_{2}(\text { diglyme })\right]_{2}, 4$}

In the synthesis of $\mathbf{4}$ was used the freshly prepared iron(II) chloride hydrate instead of the partly oxidized one. Therefore iron $(3.0 \mathrm{~g}, 53.7 \mathrm{mmol})$ reacted with hydrochloric acid $(22 \mathrm{~mL}, 18 \%)$ at $80{ }^{\circ} \mathrm{C}$ for three hours. 
Unreacted iron was removed by a hot filtration, a green solution was dried in vacuo and a moist green product resulted. Chlorine content $(33.06 \%)$ of this product was determined by potentiometric titrations and iron content (25.98\%) was calculated according to the molar ratio of iron and chlorine in $\mathrm{FeCl}_{2}$. Solvent $\left(\mathrm{CH}_{2} \mathrm{Cl}_{2}, 30 \mathrm{~mL}\right)$, diglyme $(1.410 \mathrm{~g}, 10.5 \mathrm{mmol})$ and $\left(\mathrm{CH}_{3}\right)_{3} \mathrm{SiCl}(13.13 \mathrm{~g}$, $121 \mathrm{mmol}$ ) were added to the freshly prepared green iron(II) chloride hydrate $\left(1.014 \mathrm{~g}, 4.72 \mathrm{mmol}\right.$ of $\left.\mathrm{Fe}^{2+}\right)$. The suspension was stirred for a day at room temperature and then dried in vacuo. The procedure was repeated in the second step, because some water was present in the white product, as proven by characteristic peaks (3419 s, $\left.1600 \mathrm{~m} \mathrm{~cm}^{-1}\right)$ in IR spectrum. Solvent $\left(\mathrm{CH}_{2} \mathrm{Cl}_{2}, 30 \mathrm{~mL}\right)$, diglyme $(1.410 \mathrm{~g}, 10.5 \mathrm{mmol})$ and $\left(\mathrm{CH}_{3}\right)_{3} \mathrm{SiCl}(13.13 \mathrm{~g}$, $121 \mathrm{mmol}$ ) were added to the white product. The suspension was stirred for a week at room temperature and then dried in vacuo, the complex 4 (0.959 g, 77.9\% yield) was gained. Anal. Calcd. mass fractions of elements, $w / \%$, for $\mathrm{C}_{12} \mathrm{H}_{28} \mathrm{Cl}_{4} \mathrm{O}_{6} \mathrm{Fe}_{2}\left(M_{\mathrm{r}}=521.84\right)$ are: $\mathrm{C}, 27.62 ; \mathrm{H}, 5.41 ; \mathrm{Cl}$, 27.17; found: C, 27.42; H, 5.35; Cl, 27.28. IR (4 in Nujol) $1344 \mathrm{~m}, 1281 \mathrm{~m}, 1265 \mathrm{~m}, 1247 \mathrm{~m}, 1234 \mathrm{~m}, 1208 \mathrm{w}, 1191$ w, 1112 s, 1080 s, 1060 s, 1040 s, 1010 s, 950 m, 868 s, $837 \mathrm{~s}, 828 \mathrm{~m}, 560 \mathrm{w} \mathrm{cm}^{-1}$. Recrystallization from dichloromethane resulted in colorless crystals of 4 . Magnetic moment of $4: \mu, 5.48 \mathrm{BM}$.

\section{6. Crystal Structure Determination}

Details of the crystal data collections and the refinement parameters of the complexes 1-4 are summarized in Table 1.

All studied compounds are hygroscopic. The crystals were mounted on a tip of a glass fiber with a small amount of silicon grease. Diffraction data were collected on a Nonius Kappa diffractometer with a CCD area detector at 150(2) K. Graphite monochromatic Mo $K \alpha$ radiation $(\lambda=0.71073 \AA$ ) was employed for all measurements. The data were processed using the program DENZO-SMN. ${ }^{21}$ The crystal structures were solved by direct methods implemented in SHELXS$97^{22}$ and refined by a full-matrix least-squares procedure based on $F^{2}$ (SHELXL-97). ${ }^{23}$ All non-hydrogen atoms were refined anisotropically. All hydrogen atoms were included in the models at geometrically calculated positions and refined using a riding model. The calculations were performed using the WinGX program suite. $^{24}$

Absolute structures of $\mathbf{1}$ and $\mathbf{2}$ cannot be determined reliably (Flack parameter $0.51(3)$ and $0.53(2)$ respectively). ${ }^{25}$ Figures depicting the structures were prepared by ORTEP $3^{26}$ and Mercury. ${ }^{27}$

Table 1 Crystallographic data for the compounds $\mathbf{1},\left[\mathrm{VCl}_{3}(\operatorname{diglyme})\right], \mathbf{2},\left[\mathrm{VOCl}_{2}(\operatorname{diglyme})\right], \mathbf{3},[\mathrm{FeCl}(\text { diglyme})(\mathrm{THF})]_{2}\left[\mathrm{FeCl}_{4}\right]_{2}$, and 4, $\left[\mathrm{FeCl}_{2}\left(\mathrm{diglyme}_{2}\right]_{2}\right.$

\begin{tabular}{|c|c|c|c|c|}
\hline & 1 & 2 & 3 & 4 \\
\hline Formula & {$\left[\mathrm{VCl}_{3}\left(\mathrm{O}_{3} \mathrm{C}_{6} \mathrm{H}_{14}\right)\right]$} & {$\left[\mathrm{VOCl}_{2}\left(\mathrm{O}_{3} \mathrm{C}_{6} \mathrm{H}_{14}\right)\right]$} & {$\left[\mathrm{FeCl}\left(\mathrm{O}_{3} \mathrm{C}_{6} \mathrm{H}_{14}\right)\left(\mathrm{OC}_{4} \mathrm{H}_{8}\right)\right]_{2}\left[\mathrm{FeCl}_{4}\right]_{2}$} & {$\left[\mathrm{FeCl}_{2}\left(\mathrm{O}_{3} \mathrm{C}_{6} \mathrm{H}_{14}\right)\right]_{2}$} \\
\hline Color & violet & blue & yellow & colorless \\
\hline For. mass $\left(\mathrm{g} \mathrm{mol}^{-1}\right)$ & 291.46 & 272.01 & 990.45 & 521.84 \\
\hline Crystal system & orthorhombic & monoclinic & monoclinic & monoclinic \\
\hline Space group & $P 2, c n($ no. 33$)$ & $C c$ (no. 9) & $P 2, / c($ no. 14$)$ & $P 2{ }_{1} / \mathrm{c}($ no. 14$)$ \\
\hline$a(\AA)$ & $6.9987(1)$ & $6.9947(2)$ & $12.2851(3)$ & $10.3118(4)$ \\
\hline$b(\AA)$ & $11.2312(2)$ & $11.8436(3)$ & $13.6297(3)$ & $7.5431(2)$ \\
\hline$c(\AA)$ & $28.4482(6)$ & $13.0738(4)$ & $12.2931(3)$ & $14.3736(5)$ \\
\hline$\beta\left(^{\circ}\right)$ & 90.0 & $92.918(2)$ & $109.519(1)$ & $110.547(2)$ \\
\hline$V\left(\AA^{3}\right)$ & $2236.14(7)$ & $1081.66(5)$ & $1940.09(8)$ & $1046.90(6)$ \\
\hline$Z$ (form.) & 8 & 4 & 2 & 2 \\
\hline$D_{\text {cal. }}\left(\mathrm{g} \mathrm{cm}^{-3}\right)$ & 1.732 & 1.670 & 1.695 & 1.655 \\
\hline$\mu\left(\mathrm{mm}^{-1}\right)$ & 1.577 & 1.392 & 2.191 & 1.919 \\
\hline Crystal size (mm) & 0.220 .200 .18 & 0.070 .060 .05 & 0.150 .140 .14 & 0.200 .200 .17 \\
\hline$\theta$ Range $\left(^{\circ}\right)$ & $1.43-27.48$ & $3.78-27.40$ & $3.5-27.5$ & $3.43-27.44$ \\
\hline Total numb. of collected reflections & 4941 & 2381 & 13188 & 4474 \\
\hline Number of unique reflections & 4941 & 2375 & 4415 & 2387 \\
\hline$R_{\text {int }}$ & 0.045 & 0.0155 & 0.0245 & 0.029 \\
\hline Number of reflections used & 4419 & 2301 & 3857 & 1899 \\
\hline Threshold & {$[I>2.0 \sigma(I)]$} & {$[I>2.0 \sigma(I)]$} & {$[I>2.0 \sigma(I)]$} & {$[I>2.0 \sigma(I)]$} \\
\hline Number of parameters & 239 & 121 & 192 & 111 \\
\hline$R^{\mathrm{a}}($ obs. $)$ & 0.0333 & 0.0248 & 0.0229 & 0.027 \\
\hline$w R_{2}^{\mathrm{b}}$ & 0.0692 & 0.0591 & 0.0557 & 0.055 \\
\hline$S^{2}$ & 1.044 & 1.027 & 1.015 & 1.034 \\
\hline $\begin{array}{l}\text { Maximum } / \text { minimum } \\
\text { res. elec. d. }\left(\mathrm{e} \AA^{-3}\right)\end{array}$ & $0.296,-0.401$ & $0.217,-0.339$ & $0.624,-0.294$ & $0.289,-0.354$ \\
\hline
\end{tabular}

$$
{ }^{\mathrm{a}} R=\sum\left(\left|F_{\mathrm{o}}\right|-\mid F_{\mathrm{c}}\right) / \Sigma\left|F_{\mathrm{o}}\right|{ }^{\mathrm{b}} w R_{2}=\left(\sum\left[w\left(F_{\mathrm{o}}{ }^{2}-F_{\mathrm{c}}{ }^{2}\right)^{2}\right] / \sum\left(w F_{\mathrm{o}}{ }^{2}\right)^{2}\right)^{1 / 2}
$$




\section{Results and Discussion}

\section{1. Syntheses of Vanadium Chloride Com- plexes with Diglyme, $\left[\mathrm{VCl}_{3}\right.$ (diglyme) $], 1$, and $\left[\mathrm{VOCl}_{2}\right.$ (diglyme)], 2}

A choice of solvent applied in the reaction of vanadium(III) chloride and diglyme is very important. A reaction is completed in dichloromethane at room temperature, but in tetrahydrofuran even a reaction at elevated temperature ( 20 hours, $65^{\circ} \mathrm{C}$ ) resulted in a mixture of unreacted $\mathrm{VCl}_{3}$ and complex $\mathbf{1}$. The complex $\mathbf{1}$ is a sensitive and unstable compound which is oxidized by oxygen to the $\mathrm{V}(\mathrm{IV})$ complex $\mathbf{2}$. The blue color of $\mathbf{2}$ is characteristic for almost all compounds containing a vanadyl unit.

\section{2. Crystal Structures of 1 and 2}

A distorted octahedral arrangement of ligands is observed in the mononuclear molecular complexes of $\mathbf{1}$ and 2 (Figure 1). Three oxygen atoms of a diglyme molecule

a)
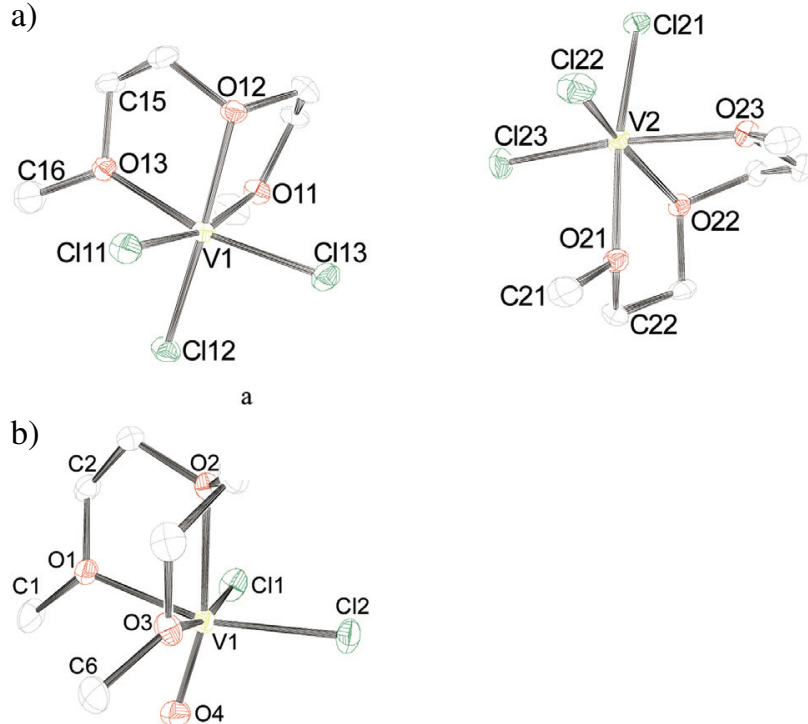

Figure 1. a) Two molecules of $\left[\mathrm{VCl}_{3}\right.$ (diglyme) $]$ in the asymmetric unit of $\mathbf{1}$. b) The crystal structure of $\mathbf{2},\left[\mathrm{VOCl}_{2}\right.$ (diglyme)], with the numbering scheme adopted. Hydrogen atoms are omitted for clarity. The probability of the thermal ellipsoids is $50 \%$.

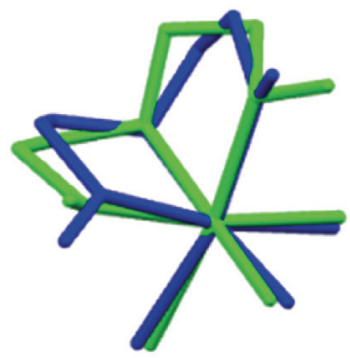

Figure 2. Two molecules of $\left[\mathrm{VCl}_{3}(\mathrm{diglyme})\right]$ in the asymmetric unit of $\mathbf{1}$ are overlaid. Hydrogen atoms are omitted for clarity. are coordinated in a facial mode to a central vanadium(III) ion in $\mathbf{1}$ or to an oxidovanadium(IV) ion in $\mathbf{2}$. The coordination sphere is fulfilled by three or two chloride ions in $\mathbf{1}$ and $\mathbf{2}$, respectively.

The overlay of two molecules in the asymmetric unit of the complex 1 clearly shows a different puckering of coordinated diglyme ligand (Figure 2).

The ring conformation differences of coordinated diglyme in two molecules of an asymmetric unit as in $\mathbf{1}$ were reported also for the isostructural complex [Ti$\mathrm{Cl}_{3}$ (diglyme)] (Figure 3). ${ }^{11} \mathrm{~A}$ similar facial geometry of a coordinated diglyme as in $\mathbf{1 , 2}$ and $\left[\mathrm{TiCl}_{3} \text { (diglyme) }\right]^{11}$ was found also in $\left[\mathrm{ScCl}_{3}\right.$ (diglyme) $],{ }^{12}$ but the smaller ${ }^{18} \mathrm{Al}^{3+}$ is coordinated by a diglyme molecule in a meridional mode in $\left[\mathrm{AlBr}_{3}(\text { diglyme })\right]^{19}$
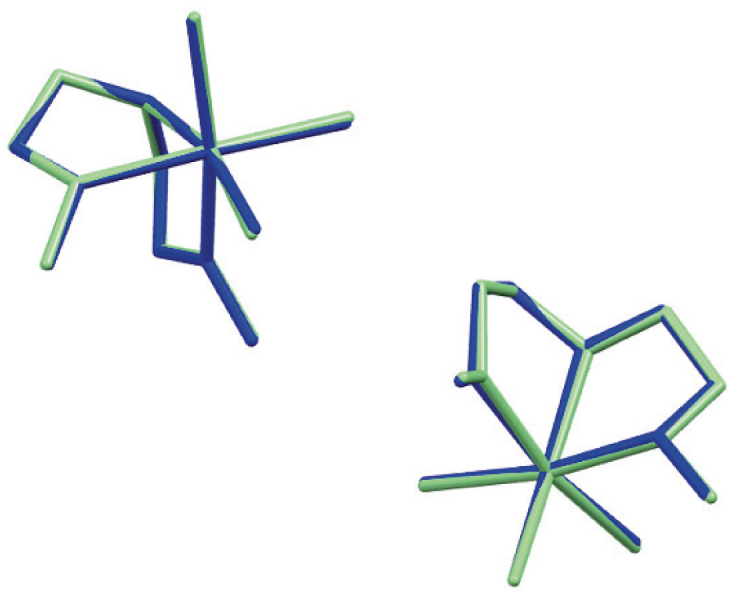

Figure 3. Structure overlay of isostructural complexes 1, $\left[\mathrm{VCl}_{3}\right.$ (diglyme) $]$, in blue and $\mathrm{TiCl}_{3}($ diglyme $\left.)\right]$ in green. ${ }^{11}$ Hydrogen atoms are omitted for clarity.

Selected geometric parameters $\left(\AA,^{\circ}\right)$ in $\mathbf{1}$ and $\mathbf{2}$ are summarized in Table 2.

Interestingly, the average $\mathrm{V}-\mathrm{Cl}$ bonding distances in $\mathbf{2}$ are longer than in $\mathbf{1}$ in spite of a higher oxidation state of vanadium in $\mathbf{2}$ than in $\mathbf{1}$.

$\mathrm{V}-\mathrm{Cl}$ bonding distances in complexes 1 are comparable to those observed in $f a c$ - $\left[\mathrm{VCl}_{3}(\mathrm{DME})(\mathrm{THF})\right]$ $(2.298(4)-2.306(6) \AA)^{28}$ and $m e r-\left[\mathrm{VCl}_{3}(\mathrm{THF})_{3}\right](2.297(1)-$ 2.333(1) $\AA$ ). ${ }^{29}$ The average V-O(diglyme) distance in $\mathbf{1}$ is in the same range as $\mathrm{V}-\mathrm{O}(\mathrm{DME})(2.119(8) \AA)$ and longer than $\mathrm{V}-\mathrm{O}$ (THF) to a sterically less demanding ligand THF in $f a c$ - $\left[\mathrm{VCl}_{3}(\mathrm{DME})(\mathrm{THF})\right](2.03(1) \AA)^{28}$ or $m e r-\left[\mathrm{VCl}_{3}(\mathrm{THF})_{3}\right](2.062(8) \AA) .{ }^{29}$

A comparison of orthorhombic vanadyl complexes $\left[\mathrm{VOCl}_{2}(\mathrm{MeOH})_{3}\right]$ and $\left[\mathrm{VOCl}_{2}\left(\mathrm{H}_{2} \mathrm{O}\right)(\mathrm{THF})_{2}\right]$ reveals similar bonding distances as in $2 .{ }^{30} \mathrm{~A}$ pronounced elongation of $\mathrm{V}-\mathrm{O}$ bonding distance trans to a short vanadyl bond similar as in $\mathbf{2}$ was found in both compared complexes. V-O distances to monodentate ligands are slightly shorter (V-O(MeOH) 2.056(5)-2.088(5) $\AA, \mathrm{V}-\mathrm{O}(\mathrm{THF})$ 2.064(2) $\AA$ ) and $\mathrm{V}-\mathrm{Cl}$ distances slightly longer 
Table 2. Selected geometric parameters $\left(\AA,^{\circ}\right)$ in $\mathbf{1},\left[\mathrm{VCl}_{3}(\operatorname{diglyme})\right]$, and $\mathbf{2},\left[\mathrm{VOCl}_{2}(\operatorname{diglyme})\right]$

\begin{tabular}{|c|c|c|c|c|}
\hline & $1,\left[\mathrm{VCl}_{3}(\mathrm{dig}\right.$ & & $2,[V$ & lyme)] \\
\hline & & & & \\
\hline $\operatorname{Vn}-\mathrm{Cln} 3$ & $2.3293(10)$ & $2.2834(10)$ & $\mathrm{V}-\mathrm{Cl} 2$ & $2.31 / 4(6)$ \\
\hline $\mathrm{Vn}-\mathrm{Cln} 2$ & $2.2655(9)$ & $2.3183(9)$ & V-Cl1 & $2.3318(6)$ \\
\hline Vn-Cln1 & $2.2798(10)$ & $2.2849(9)$ & $\mathrm{V}-\mathrm{Cl}_{\mathrm{av}}$ & $2.325(1)$ \\
\hline $\mathrm{Vn}-\mathrm{Cl}_{\mathrm{av}}$ & $2.291(3)$ & $2.296(3)$ & $\mathrm{V}-\mathrm{O} 1$ & $2.102(1)$ \\
\hline Vn-On1 & $2.185(2)$ & $2.108(2)$ & $\mathrm{V}-\mathrm{O} 2$ & $2.237(2)$ \\
\hline Vn-On2 & $2.088(2)$ & $2.088(2)$ & $\mathrm{V}-\mathrm{O} 3$ & $2.146(2)$ \\
\hline Vn-On3 & $2.120(2)$ & $2.102(2)$ & $\mathrm{V}-\mathrm{O}_{\mathrm{av}(\text { diglyme })}$ & $2.162(6)$ \\
\hline $\mathrm{Vn}-\mathrm{On}_{\mathrm{av}}$ & $2.131(6)$ & $2.099(6)$ & $\mathrm{V}-\mathrm{O} 4$ & $1.592(2)$ \\
\hline$\overline{\mathrm{On} 1-\mathrm{Vn}-\mathrm{On} 3}$ & $88.23(9)$ & $82.43(9)$ & $\mathrm{O} 1-\mathrm{V}-\mathrm{O} 3$ & $85.98(6)$ \\
\hline On2-Vn-On3 & 76.03(9) & $78.37(9)$ & $\mathrm{O} 3-\mathrm{V}-\mathrm{O} 2$ & $73.83(6)$ \\
\hline On1-Vn-On2 & $74.60(8)$ & $76.80(9)$ & $\mathrm{O} 1-\mathrm{V}-\mathrm{O} 2$ & $72.60(6)$ \\
\hline $\mathrm{Cln} 1-\mathrm{Vn}-\mathrm{Cln} 2$ & $100.57(4)$ & $97.12(3)$ & $\mathrm{Cl} 2-\mathrm{V}-\mathrm{Cl} 1$ & $93.35(2)$ \\
\hline $\mathrm{Cln} 2-\mathrm{Vn}-\mathrm{Cln} 3$ & $97.65(4)$ & $96.45(4)$ & O4-V-O1 & $94.82(7)$ \\
\hline $\mathrm{Cln} 1-\mathrm{Vn}-\mathrm{Cln} 3$ & $93.54(4)$ & $96.58(4)$ & $\mathrm{O} 4-\mathrm{V}-\mathrm{O} 3$ & $90.75(7)$ \\
\hline On1-Vn-Cln1 & $168.06(6)$ & $166.60(7)$ & $\mathrm{O} 4-\mathrm{V}-\mathrm{O} 2$ & $160.46(7)$ \\
\hline On2-Vn-Cln2 & $160.91(7)$ & $167.38(7)$ & $\mathrm{O} 4-\mathrm{V}-\mathrm{Cl} 2$ & $102.64(6)$ \\
\hline On3-Vn-Cln3 & $170.18(7)$ & $168.36(7)$ & $\mathrm{O} 3-\mathrm{V}-\mathrm{Cl} 1$ & $166.85(5)$ \\
\hline
\end{tabular}

in $\quad\left[\mathrm{VOCl}_{2}(\mathrm{MeOH})_{3}\right] \quad(2.359(3)-3.386(2) \quad \AA)$ and $\left[\mathrm{VOCl}_{2}\left(\mathrm{H}_{2} \mathrm{O}\right)(\mathrm{THF})_{2}\right](3.3804(6) \AA)$ than in $2 .{ }^{30}$ Similar, very short $\mathrm{V}=\mathrm{O}$ distances as in $\mathbf{2}$ were observed also in oxidovanadium(V) complexes (1.583(3) $\AA, 1.592(1)$ $\AA) .{ }^{31}$

\section{3. Syntheses of Iron Chloride Complexes with Diglyme, $[\mathrm{FeCl} \text { (diglyme)(THF) }]_{2}$ $\left.\left[\mathrm{FeCl}_{4}\right)\right]_{2}, 3$, and $\mathrm{FeCl}_{2}$ (diglyme) $]_{2}, 4$}

Only a few crystals of iron(II)-iron(III) complex 3 were obtained when partly oxidized $\mathrm{FeCl}_{2} \cdot 4 \mathrm{H}_{2} \mathrm{O}$ was used in the synthesis of iron chloride complex with diglyme. A reaction of the freshly prepared green iron(II) chloride hydrate, diglyme and $\left(\mathrm{CH}_{3}\right)_{3} \mathrm{SiCl}$ in excess, which should guarantee a formation of a water free complex, ${ }^{32}$ resulted in an aqua iron chloride complex with diglyme. The complex 4 was gained only in the reaction of the aqua iron chloride complex with $\left(\mathrm{CH}_{3}\right)_{3} \mathrm{SiCl}$ and diglyme in dichloromethane. A one step synthesis of $\mathbf{4}$ was not successful even with a prolonged reaction time and a higher $\left(\mathrm{CH}_{3}\right)_{3} \mathrm{SiCl}$ content in a reaction mixture of freshly prepared moist green iron(II) chloride hydrate and diglyme in dichloromethane. A similar two step reaction was reported for a dehydration of $\mathrm{FeCl}_{2} \cdot 4 \mathrm{H}_{2} \mathrm{O}$ by triethyl orthoformate in propan-2-ol yielding $\left[\mathrm{FeCl}_{2}(\mathrm{PrOH})_{2}\right]_{\mathrm{n}} \cdot{ }^{33}$

\section{4. Magnetic Measurements}

The magnetic moment of iron complex 4 (5.48 BM) measured at room temperature suggests a high spin $d^{6}$ configuration of octahedrally coordinated $\mathrm{Fe}^{2+}$ ions. ${ }^{20}$

\section{5. Crystal structures of 3 and 4}

Two bridging chloride ions and three oxygen atoms of a diglyme molecule in a meridional mode are coordinated to each of two iron centers connected into a cation of $\mathbf{3}$ or a dinuclear molecule 4 (Figure 4). A distorted octahedral arrangement of iron(II) ions is fulfilled by a non-brid-

a)

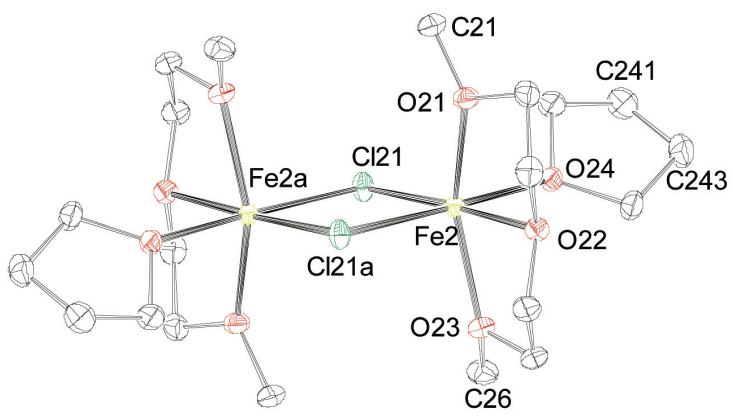

b)

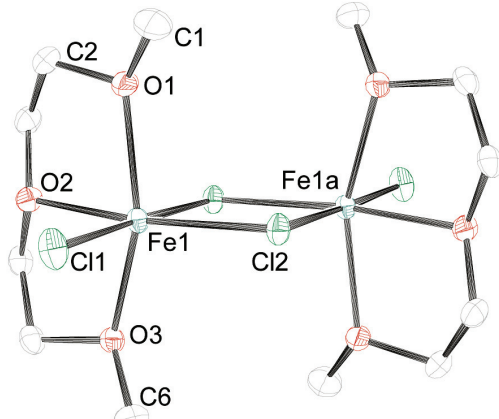

Figure 4. a) A cation of 3, $[\mathrm{FeCl}(\operatorname{diglyme})(\mathrm{THF})]_{2}{ }^{+}$. b) The crystal structures of dinuclear molecular complex $\mathbf{4},\left[\mathrm{FeCl}_{2} \text { (diglyme) }\right]_{2}$ with the numbering scheme adopted. Hydrogen atoms are omitted for clarity. The probability of the thermal ellipsoids is $50 \%$. 
ging chloride in $\mathbf{4}$ and by an oxygen atom from THF molecule in cation of $\mathbf{3}$.

A rhombus $\mathrm{M}-\mathrm{Cl}-\mathrm{M}-\mathrm{Cl}$ is almost the same in $\mathbf{4}$ and isostructural complexes of manganese(II), nickel(II) and cobalt(II), ${ }^{13}, 15$ while ring conformation of coordinated diglyme molecules slightly differs (Figure 5).

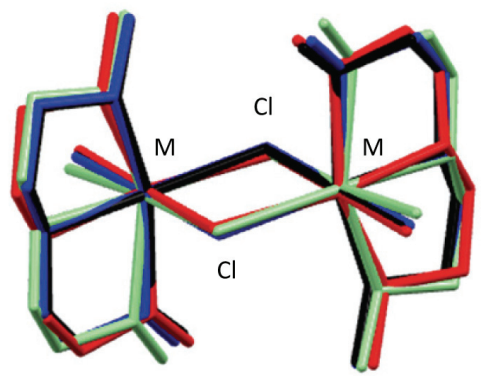

Figure 5. Structure overlay of isostructural complexes $\left[\mathrm{MCl}_{2} \text { (diglyme) }\right]_{2},(\mathrm{M}=\mathrm{Fe}$ in red; $\mathrm{Mn}$ in green, $\mathrm{Ni}$ in black and $\mathrm{Co}$ in blue). ${ }^{13},{ }^{15}$ Hydrogen atoms are omitted for clarity.

Selected geometric parameters $\left(\AA,{ }^{\circ}\right)$ in $\mathbf{3}$ and $\mathbf{4}$ are summarized in Table 3.

The average $\mathrm{Fe}-\mathrm{Cl}$ (bridging), $\mathrm{Fe}-\mathrm{O}$ (diglyme) bonding distances and distances between two $\mathrm{Fe}^{2+}$ ions linked by two $\mu$-bridging chlorides are shorter in a cation of $\mathbf{3}$ than in a dinuclear complex 4.

$\mathrm{M}-\mathrm{O}$ and $\mathrm{M}-\mathrm{Cl}$ bonding distances in $\mathbf{4}$ and isostructural $\left[\mathrm{MCl}_{2}(\text { diglyme })\right]_{2}(\mathrm{M}=\mathrm{Mn}, \mathrm{Co} \text { and } \mathrm{Ni})^{13,15}$ decrease perfectly in accord to the decreasing ionic radii of the transition metal atoms from manganese to nickel. ${ }^{18}$

$\mathrm{Fe}-\mathrm{Cl}$ (bridging) and $\mathrm{Fe}-\mathrm{O}$ bonding distances in cations of $\mathbf{3}$ are in the same range as in a tetranuclear complex $\left[\mathrm{Fe}_{4} \mathrm{Cl}_{8}(\mathrm{THF})_{6}\right]\left(\mathrm{Fe}-\left(\mu^{2}-\mathrm{Cl}\right) 2.355(1)-2.488(2) \AA\right.$ and average $\mathrm{Fe}-\mathrm{O} 2.135(9) \AA) .{ }^{34} \mathrm{~A}$ comparison of geometric parameters in mixed $\mathrm{Fe}(\mathrm{II}), \mathrm{Fe}$ (III) complex $\mathbf{3}$ and in a $\mathrm{Fe}(\mathrm{III})$ complex $\left[\mathrm{FeCl}_{2}(\mathrm{DME})_{2}\right]\left[\mathrm{FeCl}_{4}\right](\mathrm{Fe}-\mathrm{Cl}$ in anion $2.1895(9)-2.200(1) \AA)^{35}$ indicates similarity of anions and thus confirming the $3+$ oxidation number of iron in anion of 3 . The average $\mathrm{Fe}-\mathrm{O}$ bonding distances in $\mathbf{3}$ are longer than in $\left[\mathrm{FeCl}_{2}(\mathrm{DME})_{2}\right]^{+}(2.101(4) \AA)^{35}$ due to a lower oxidation number of iron in cation of $\mathbf{3}$.

\section{Conclusions}

A chelate $\eta^{3}$, non-bridging coordination of diglyme as characteristic for all complexes of the first row $d$-block metals ${ }^{13-16}$ was found in the four novel vanadium and iron complexes 1-4. The new complex of vanadium(III) chloride with diglyme $\mathbf{1}$ is a mononuclear compound with a facial arrangement of $\mathrm{O}$-donor atoms from diglyme, which has been already reported for $\left[\mathrm{MCl}_{3}\right.$ (diglyme) $]$ ( $\mathrm{M}$ $=\mathrm{Sc}, \mathrm{Ti}) \cdot{ }^{11,12}$ The facial coordination of diglyme molecule is retained in the vanadyl complex $f a c$-[ $\mathrm{VOCl}_{2}$ (diglyme)], $\mathbf{2}$, achieved by an oxidation of $\left[\mathrm{VCl}_{3}(\right.$ diglyme $\left.)\right], \mathbf{1}$, in the presence of air.

The new compound of iron(II) chloride with diglyme 4 is a dinuclear complex with two bridging chlorides to achieve a preferred octahedral environment of the central $\mathrm{Fe}^{2+}$. Diglyme is in $\left[\mathrm{FeCl}_{2} \text { (diglyme) }\right]_{2}, \mathbf{4}$, coordinated to $\mathrm{Fe}^{2+}$ in the meridional mode similarly as in all reported $\mathrm{M}$ (II) complexes with an octahedral geometry. ${ }^{13-17} \mathrm{In}$ the iron(II)-iron(III) complex $[\mathrm{FeCl} \text { (diglyme)(THF) }]_{2}$ $\left.\left[\mathrm{FeCl}_{4}\right)\right]_{2}, \mathbf{3}$, diglyme is coordinated to $\mathrm{Fe}^{2+}$. Two iron(II) ions in the cation are linked by bridging chlorides and diglyme is also coordinated in a meridional geometry.

Table 3. Selected geometric parameters $\left(\AA{ }^{\circ}{ }^{\circ}\right)$ in $\mathbf{3},[\mathrm{FeCl}(\text { diglyme})(\mathrm{THF})]_{2}\left[\mathrm{FeCl}_{4}\right]_{2}$, and $\mathbf{4},\left[\mathrm{FeCl}_{2}(\operatorname{diglyme})\right]_{2}$

\begin{tabular}{|c|c|c|c|c|c|}
\hline \multicolumn{2}{|c|}{$[\mathrm{FeCl}(\text { diglyme })(\mathrm{THF})]_{2}^{2+}$} & \multicolumn{2}{|c|}{$\left[\mathrm{FeCl}_{4}\right]^{-}$} & \multicolumn{2}{|c|}{$\begin{array}{c}4 \\
{\left[\mathrm{FeCl}_{2}(\text { diglyme })\right]_{2}}\end{array}$} \\
\hline $\mathrm{Fe} 2-\mathrm{Cl} 21$ & $2.3804(4)$ & Fe1-Cl11 & $2.1938(5)$ & Fe1-Cl1 & $2.3511(5)$ \\
\hline $\mathrm{Fe} 2-\mathrm{Cl} 21 \mathrm{a}$ & $2.5098(4)$ & $\mathrm{Fe} 1-\mathrm{Cl} 12$ & $2.1966(5)$ & $\mathrm{Fe} 1-\mathrm{Cl} 2$ & $2.4348(5)$ \\
\hline $\mathrm{Fe} 2-\mathrm{Cl}_{\mathrm{av}}$ & $2.445(1)$ & $\mathrm{Fe} 1-\mathrm{Cl} 13$ & $2.1968(5)$ & $\mathrm{Fe} 1-\mathrm{Cl} 2 \mathrm{a}$ & $2.5154(5)$ \\
\hline $\mathrm{Fe} 2-\mathrm{O} 21$ & $2.1046(12)$ & $\mathrm{Fe} 1-\mathrm{Cl1} 4$ & $2.1839(5)$ & $\mathrm{Fe} 2-\mathrm{Cl}_{\text {av.(bridg.) }}$ & $2.475(1)$ \\
\hline $\mathrm{Fe} 2-\mathrm{O} 22$ & $2.1740(11)$ & & & $\mathrm{Fe} 1-\mathrm{O} 1$ & $2.2052(13)$ \\
\hline $\mathrm{Fe} 2-\mathrm{O} 23$ & $2.1378(11)$ & & & $\mathrm{Fe} 1-\mathrm{O} 2$ & $2.1673(13)$ \\
\hline $\mathrm{Fe} 1-\mathrm{O}_{\text {av.(diglym) }}$ & $2.139(3)$ & & & $\mathrm{Fe} 1-\mathrm{O} 3$ & $2.1941(13)$ \\
\hline $\mathrm{Fe} 2-\mathrm{O} 24$ & $2.1506(11)$ & & & $\mathrm{Fe} 1-\mathrm{O}_{\mathrm{av} . \text { (diglyme) }}$ & $2.189(3)$ \\
\hline $\mathrm{Fe} 2-\mathrm{Fe} 2 \mathrm{a}$ & $3.5506(4)$ & & & Fe1-Fe1a & $3.6522(5)$ \\
\hline $\mathrm{Fe} 2-\mathrm{Cl} 21-\mathrm{Fe} 2 \mathrm{a}$ & $93.07(1)$ & $\mathrm{Cl11-Fe1-Cl12}$ & $109.71(2)$ & $\mathrm{Fe} 1-\mathrm{Cl} 2-\mathrm{Fe} 1 \mathrm{a}$ & $95.07(2)$ \\
\hline $\mathrm{Cl} 21-\mathrm{Fe} 2-\mathrm{O} 22$ & $177.73(3)$ & Cl11-Fe1-Cl14 & $109.98(2)$ & $\mathrm{Cl} 1-\mathrm{Fe} 1-\mathrm{Cl} 2 \mathrm{a}$ & $177.72(2)$ \\
\hline $\mathrm{Cl} 21-\mathrm{Fe} 2-\mathrm{Cl} 21 \mathrm{a}$ & $86.93(2)$ & $\mathrm{Cl} 12-\mathrm{Fe} 1-\mathrm{Cl} 13$ & $110.15(2)$ & $\mathrm{Cl} 2-\mathrm{Fe} 1-\mathrm{Cl} 2 \mathrm{a}$ & $84.93(2)$ \\
\hline $\mathrm{O} 21-\mathrm{Fe} 2-\mathrm{O} 22$ & 75.93(4) & Cl12-Fe1-Cl14 & $109.17(2)$ & $\mathrm{O} 1-\mathrm{Fe} 1-\mathrm{O} 2$ & $76.77(5)$ \\
\hline $\mathrm{O} 22-\mathrm{Fe} 2-\mathrm{O} 23$ & $75.53(4)$ & Cl13-Fe1-Cl14 & $108.85(2)$ & $\mathrm{O} 1-\mathrm{Fe} 1-\mathrm{O} 3$ & $150.20(5)$ \\
\hline $\mathrm{O} 21-\mathrm{Fe} 2-\mathrm{O} 23$ & $151.44(5)$ & & & $\mathrm{O} 2-\mathrm{Fe} 1-\mathrm{O} 3$ & $75.83(5)$ \\
\hline $\mathrm{O} 21-\mathrm{Fe} 2-\mathrm{O} 24$ & $90.61(5)$ & & & $\mathrm{O} 2-\mathrm{Fe} 1-\mathrm{Cl} 2$ & $171.49(4)$ \\
\hline $\mathrm{Cl} 21 \mathrm{a}-\mathrm{Fe} 2-\mathrm{O} 23$ & 91.91(3) & & & & \\
\hline $\mathrm{Cl} 21 \mathrm{a}-\mathrm{Fe} 2-\mathrm{O} 24$ & $178.28(3)$ & & & & \\
\hline
\end{tabular}




\section{Appendix A. Supplementary Data}

Crystallographic data for the structures 1 (CCDC 1031640), 2 (CCDC 1031641), 3 (CCDC 1031639) and 4 (CCDC 1031642) have been deposited with the Cambridge Crystallographic Data Centre. Copies of the data can be obtained free of charge via http://www.ccdc.cam.ac.uk/ conts/retrieving.html or from CCDC, 12 Union Road, Cambridge CB2 1EZ, UK; Fax: (+44) 1223 336033; or email deposit@ccdc.cam.ac.uk.

\section{Acknowledgement}

This work was supported by the Slovenian Research Agency (Research Program P1-0175).

\section{References}

1. W. Maudez, K. M. Fromm, Z. Anorg. All. Chem. 2012, 638, 1810-1819.

2. W. D. Buchanan, M. A. Guino-o, K. Ruhlandt-Senge, Inorg. Chem. 2010, 49, 7144-7155.

3. K. M. Fromm, Chem. Eur. J. 2001, 7, 2236-2244.

4. N. P. Kuzmina, D. M. Tsymbarenko, I. E. Korsakov, Z. A. Starikova, K. A. Lysenko, O. V. Boytsova, A. V. Mironov, I. P. Malkerova, A. S. Alikhanya, Polyhedron 2008, 27, 2811-2818. http://dx.doi.org/10.1016/j.poly.2008.06.021

5. S. Petriček, Z. Anorg. All. Chem. 2005, 631, 1947-1952.

6. S. Petriček, Z. Anorg. All. Chem. 2008, 634, 377-381.

7. S. Petriček, N. Senčar, Z. Anorg. All. Chem. 2008, 634, 377-381.

8. S. Petriček, Acta Chim. Slov. 2009, 56, 426-433.

9. G. B. Deacon, T. Feng, P. C Junk, G. Meyer, N. M. Scott, B. W. Skelton, A. H. White, Aust. J. Chem. 2000, 53, 853-865.

10. K. V. Vasudevan, N. A. Smith, B. L. Scott, B. L. Bennett, R. E. Muenhausen, J. C. Gordon, Dalton Trans. 2012, 41, 1924-1927.

11. M. G. B. Drew, J. A. Hutton, J. Chem. Soc., Dalton Trans. 1978, 1176-1179.

12. V. Ripert, L. G. Hubert-Pfalzgraf, J. Vaissermann, Polyhedron 1999, 18, 1845-1851.

13. S. Petriček, A. Demšar, Polyhedron 2010, 29, 3329-3334.
14. S. Petriček, Croat. Chem. Acta 2011, 84, 515-520.

15. A. Crochet, K. Fromm, Z. Anorg. Allg. Chem. 2010, 636, 1484-1496.

16. R. S. Pilato, T. Terry, A. L. Rheingold, Private communication in CSD 2009 (Refcode: COTJEB)

17. N. Metzler, H. Nöth, M. Schmidt, A. Treitl, Z. Naturforsch. 1994, $49 b, 1448-1451$.

18. R. D. Shannon, Acta Crystallog. 1976, A32, 751-767.

19. L. Jakobsmeier, I. Krossing, H. Nöth, M. J. H. Schmidt, Z. Naturforsch. 1996, 51 b, 1117-1126.

20. R. L. Dutta and A. Syamal, Elements of Magnetochemistry, second ed., Affiliated East - West PVT LTD, New Delhi, 1993.

21. Z. Otwinowski, W. Minor, Methods Enzymol. 1997, 276, 307-326.

22. G. M. Sheldrick, SHELXS-97, A Program for Automatic Solution of Crystal Structures, University of Göttingen, Göttingen, Germany, 1997.

23. G. M. Sheldrick, SHELXL-97, A Program for Crystal Structure Refinement, University of Göttingen, Göttingen, Germany, 1997.

24. L. J. Farrugia, J Appl Crystallogr. 1999, 32, 837-838.

25. L. J. Farrugia, J. Appl. Crystallogr. 1997, 30, 565. http://dx.doi.org/10.1107/S0021889897003117

26. H. D. Flack, Acta Cryst. 1983, A39, 876-881. http://dx.doi.org/10.1107/S0108767383001762

27. Mercury 3.3, Cambridge Crystallographic Data Centre.

28. G. Pampaloni, U. Englert, Inorganica Chimica Acta 1995, 231, 167-173.

29. F. A. Cotton, S. A. Duraj, G. 1. Powell, W. J. Roth, Inorganica Chimica Acta 1986, 113, 81-85.

30. D. Papoutsakis, A. S. Ichimura, V. G. Young, Jr., J. E. Jackson, D. G. Nocera, Dalton Trans. 2004, 224-228. http://dx.doi.org/10.1039/b309432d

31. K. H. Yang, Acta Chim. Slov. 2014, 61, 629-636.

32. S. Petriček, A. Demšar, L. Golič, J. Košmrlj, Polyhedron 2000, 19, 199-204.

33. G. G. Nunes, R. C. R. Bottini, D. M. Reis, P. H. C. Camargo, D. J. Evans, P. B. Hitchcock, G. J. Leigh, E. L. Sa, J. F. Soares, Inorganica Chimica Acta 2004, 357, 1219-1228.

34. F. A. Cotton, R. L. Luck, K. A. Son, Inorganica Chimica Acta 1991, 179, 11-15.

35. A. Malassa, H. Görls, A. Buchholz, W. Plass, M. Westerhausen, Z. Anorg. Allg. Chem. 2006, 632, 2355-2362. 


\section{Povzetek}

Enojedrni molekulski kompleks $f a c-\left[\mathrm{VCl}_{3}(\right.$ diglyme $\left.)\right](\mathbf{1})$ je bil sintetiziran $\mathrm{z}$ reakcijo med $\mathrm{VCl}_{3}$ in polietrom diglyme (diglyme $=$ di $(2-m e t o k s i e t i l) e t e r) \mathrm{v}$ diklorometanu. Vijolično obarvani kompleks 1 se v prisotnosti kisika iz zraka počasi oksidira, nastane moder enojedrni kompleks $f a c-\left[\mathrm{VOCl}_{2}\right.$ (diglyme)] (2).

Kompleks $\left.[\mathrm{FeCl}(\text { diglyme })(\mathrm{THF})]_{2}\left[\mathrm{FeCl}_{4}\right)\right]_{2}(3)$, ki vsebuje železo(II) in železo(III), je nastal z reakcijo rumeno zelenega, delno oksidiranega $\mathrm{FeCl}_{2} \cdot 4 \mathrm{H}_{2} \mathrm{O}$, polietra diglyme in klorotrimetilsilana v tetrahidrofuranu. Spojino sestavljajo dvojedrni kationi z oktaedrično koordiniranim železom(II) in tetraedričnimi anioni v katerih je centralni ion železo(III). Kompleks čistega železovega(II) klorida z ligandom diglyme $\left[\mathrm{FeCl}_{2} \text { (diglyme) }\right]_{2}$ (4) je bil sintetiziran iz sveže pripravljenega železovega(II) klorida hidrata, polietra diglyme in klorotrimetilsilana v diklorometanu. Ligand diglyme je koordiniran meridialno na centralni železov(II) ion tako v dvojedrnem kationu spojine 3 kot v dvojedrnih molekulah 4. 